Chapter 12

\title{
HCV, Mixed Cryoglobulinemia and Malignant Lymphoproliferation
}

\author{
Gianfranco Lauletta \\ Additional information is available at the end of the chapter \\ http://dx.doi.org/10.5772/55474
}

\section{Introduction}

Hepatitis C virus (HCV) is a member of the family Flaviviridae, genus Hepacivirus, and about 200 million people worldwide are thought to be infected [1]. Some $80 \%$ of HCV-infected individuals will develop chronic hepatitis, with 10-20\% eventually developing cirrhosis and $1-5 \%$ progressing to hepatocarcinoma [2]. The HCV genome is about 9,600 kb in length and encodes a single protein from an open reading frame of over 9024 nucleotides. This single polyprotein is subsequently cleaved into several structural and non-structural proteins. The structural proteins consist of the core and two envelope proteins (E1 and E2), starting from the $5^{\prime}$ end [1]. The ion-channel protein p7 derives from E2 cleavage [3] and is followed by the six non-structural proteins, namely, NS2, NS3, NS4A, NS4B, NS5A, and NS5B. During the replicative stage, HCV genomic RNA is transcribed into a complementary RNA strand. This "negative" strand constitutes a template for new genomic synthesis and its identification in an infected host provides convincing evidence of active viral replication [4]. Viral proteins are the result of the co- and post-translational cleavage of a single polyprotein, while host peptidases catalyze the cleavage of structural proteins. The HCV particles form a membraneassociated replication complex; after genome amplification and protein expression, progeny virions are assembled and released $[5,6]$.

Although HCV is primarily hepatotropic, clinically it is characterized by the emergence of several extrahepatic manifestations. In fact, after the identification of $\mathrm{HCV}$ as the etiologic agent of non-A, non-B chronic hepatitis and the availability in the early 1990s of a serologic test for the demonstration of IgG anti-HCV, several authors described an intriguing association between HCV infection and "essential" mixed cryoglobulinemia (MC), an immune complexmediated vasculitis involving small vessels, with some geographic differences [7-9]. This association was subsequently confirmed by the detection of viral genome in the sera of 
cryoglobulinemic patients, with a selective concentration of viral RNA in cryoprecipitates [10, 11]. The incidence of $\mathrm{HCV}$ infection in MC ranges from 40 to $90 \%$ [12] whereas $\mathrm{HCV}$-negative $\mathrm{MC}$ accounts for about $5-10 \%$ of the total cases [13].

Since B-cell clonal expansion is a hallmark of MC [14], the malignant evolution of these cells may reflect the occurrence of additional genetic accidents [15].

Here, we discuss the currently accepted pathogenetic mechanisms underlying cryoglobulinemic vasculitis and its specific clinical manifestations, the molecular events proposed to explain the potentially malignant evolution of $\mathrm{MC}$, the many clinical features of the disease, and the currently available therapeutic options for the treatment of MC and B-cell NHLs.

\section{Mixed cryoglobulinemia: Clinical features}

Cryoglobulins are immunoglobulins (Igs) that are insoluble at low temperature (below $37^{\circ} \mathrm{C}$ ) but redissolve after warming. In 1933, Wintrobe and Buell first described the phenomenon of cryoprecipitation in the serum of a patient with multiple myeloma [16], although the term "cryoglobulin" was introduced in 1947 by Lerner and Watson [17]. Meltzer et al., in a study of 29 patients, associated cryoglobulin production with a clinical picture characterized by a typical symptomatologic triad of purpura, weakness, and arthralgias. These patients were also observed to have increased serum levels of rheumatoid factor (RF) and/or organ dysfunction [18].

According to Brouet's immunochemically based classification, cryoglobulins are either single (type I) or mixed (type II and III) in their composition [19]. Thus, type I cryoglobulinemia consists of a monoclonal Ig, usually of IgM or IgG isotype. IgM cryoglobulins occur in $\sim 6 \%$ of malignant IgM paraproteinemias and IgG cryoglobulins in $\sim 2 \%$ of all myelomas. Type I IgA cryoglobulins are rare [20]. In type II MC, which accounts for $50-60 \%$ of all cryoglobulins, there is an IgM monoclonal component, frequently consisting of light $\mathrm{k}$ chains, and polyclonal IgG. IgM molecules have RF activity and are thus capable of reacting with intact IgG and/or its $\mathrm{F}(\mathrm{ab}) 2^{\prime}$ fragment [21]. In type III MC, which accounts for 30-40\% of cryoglobulins, a monoclonal component is lacking. According to some authors, this type represents a transitional form that evolves into type II MC [22].

Mixed cryoglobulins are potentially present in connective tissue and autoimmune diseases and in chronic infections [23,24]. The term "essential" defines cryoglobulinemic syndromes without an underlying identifiable etiology. It is now accepted that $\mathrm{MC}$ most often occurs in patients chronically infected with HCV [25], as the result of specific interactions between the virus and the host immune system [11]. Thus, while initially considered as "essential", MC is now recognized as the most common HCV-related extrahepatic disease. It has been estimated that $40-60 \%$ of chronically HCV-infected patients produce cryoglobulins, but only $15-20 \%$ will develop the full-blown clinical features of MC [26].

The prevalence of MC shows great heterogeneity in terms of geographic distribution. The disease seems to be more common in Southern Europe and in the Mediterranean basin than 
in Northern Europe and North America [27]. Although MC is considered to be a rare disorder, with an estimated prevalence of approximately of 1:100,000 (with a F:M ratio of 3:1), its true prevalence is unknown because of a failure by the treating physician to recognize the clinical symptoms such that patients are referred to several specialists and are often incorrectly diagnosed.

Cryoglobulinemic syndrome can be considered an immune-mediated systemic vasculitis preferentially affecting the small and medium-sized vessels. Although Meltzer's symptomatologic triad of purpura, weakness, and arthralgias is considered diagnostic, the clinical spectrum of cryoglobulinemic vasculitis varies depending on the exact organ involvement.

\subsection{Skin tissue}

Cutaneous manifestations are the most typical clinical sign of cryoglobulinemic vasculitis; they range from palpable purpura of the lower limbs to chronic torpid cutaneous ulcers typically located in the supramalleolar regions. Usually, the clinical course of the purpura consists of recurrent flares in which the lesions spontaneously heal but leave a characteristic brown pigmentation due to residual hemosiderin deposits. Less frequently, purpura can extend from the abdomen, upper limbs, and thorax. Although small petechial lesions are typically seen on the skin, other manifestations have been described, including Raynaud's phenomenon, livedo reticularis, urticaria, and edema. The cutaneous involvement is often complicated by the occurrence of chronic leg ulcers with little or no tendency to heal and which spontaneously cause pain and severe discomfort to the patient (Figure 1) [28].

The histopathologic features of palpable purpura include a non-specific inflammatory infiltrate involving the small vessels (leukocytoclastic vasculitis), sometimes with a mononuclear cells infiltration of the vessel walls. Endoluminal thrombi and fibrinoid necrosis of the arteriolar walls have also been described [29].

As previously reported, skin lesions are almost invariable associated with arthralgias, which often symmetrically involve the hands and knees. Weakness is nearly always present.

\subsection{Kidney}

Kidney involvement is a common feature of an immune-complex-mediated systemic vasculitis. Renal injury complicates MC in almost $30 \%$ of the cases and is present at the time of diagnosis in $20 \%$ [12, 30, 31]. In about $50 \%$ of the cases, renal failure follows an indolent course, whereas nephritic or nephrotic syndrome occurs in $14 \%$ and $21 \%$ of MC patients, respectively [32]. The most common clinical features are hypertension, proteinuria, microhematuria, and red blood cell casts. A definitive cryoglobulinemic glomerulonephritis evolves into chronic renal failure in $14 \%$ of patients after a mean follow-up of 6 years [33].

Although kidney involvement is a common feature of systemic vasculitis, cryoglobulinemic nephropathy is considered a distinct clinical and pathological entity and the etiological role of $\mathrm{HCV}$ in the disease has been extensively investigated [34]. Type I membranoproliferative glomerulonephritis is predominantly associated with HCV infection [35, 36]. Light microscopy 


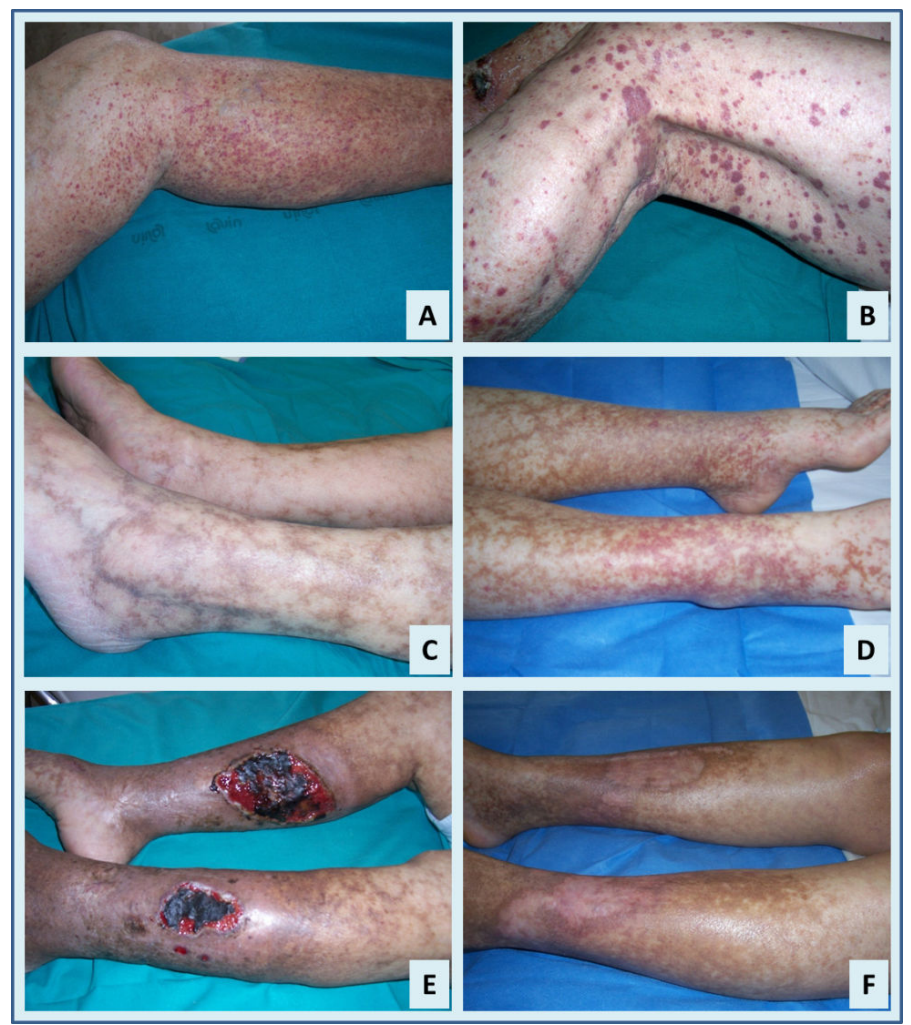

Figure 1. Clinical manifestation of cryoglobulinemic vasculitis. (A) Typical purpuric lesions, seen here on the legs, may become confluent (B). (C) and (D): livedo reticularis. (E) Chronic leg ulcers. (F) Ulcers healing after therapy

of biopsy samples shows a pronounced glomerular lobulation with a diffuse thickening of the glomerular capillary walls and a monocytic infiltration. PAS-positive hyaline thrombi may be observed inside capillary lumina $[35,37]$. The mechanism of $\mathrm{HCV}$-induced renal damage is unclear. However, HCV core protein has been detected in a homogeneous distribution along the glomerular capillary wall and tubulo-interstitial blood vessels [38] in association with an anti-core activity, suggesting a major role for these immune complexes in the pathogenesis of renal damage [39].

\subsection{Nervous system}

The involvement of the nervous system in the course of $\mathrm{HCV}$-related $\mathrm{MC}$ ranges from $17 \%$ to $60 \%$ [40]. In some cases, however, peripheral neuropathy is the first clinical sign of cryoglobulinemia [41]. Peripheral nervous system involvement may complicate MC by causing a sensory-motor neuropathy, especially of the lower limbs, with paresthesias as well as loss of strength, pain, and burning sensations [42]. Central nervous system involvement, characterized by transient dysarthria, hemiplegia, and confusional state, is less frequently seen [43]. 


\subsection{Liver}

As HCV infection represents the underlying condition characterizing $\mathrm{MC}$, the liver is involved in almost $70 \%$ of cases. In the majority, the clinical picture consists of a chronic hepatitis with the histopathologic features of chronic active hepatitis, potentially leading to cirrhosis and hepatocellular carcinoma $[7,44]$.

\subsection{Gastroenteric and pulmonary systems}

Gastrointestinal and pulmonary involvement are less common, occurring in 2-6\% and 5\% of cases, respectively. Intestinal ischemia may arise, with acute abdominal pain. Intestinal perforation and symptoms that mimic cholecystitis and/or pancreatitis have also been described [45].

Lung involvement in MC is characterized by interstitial pneumopathy; these patients typically present with dyspnea and dry cough. An acute alveolar hemorrhage with hemoptysis, respiratory failure, and a radiologic demonstration of multiple infiltrates occurs only rarely $[46,47]$.

\subsection{Classification of cryoglobulinemic vasculitis}

Currently, there are no commonly accepted classification criteria for cryoglobulinemic vasculitis, even if accurate diagnosis and staging are crucial in order to establish a more precise clinical and therapeutic approach to this multifaceted disease. Recently, the Italian Study Group on Cryoglobulinemia (GISC) proposed preliminary classification criteria for cryoglobulinemic vasculitis [48]. Drawing on other classification systems designed to assess autoimmune diseases such as Sjögren's syndrome, the preliminary criteria for the classification of cryoglobulinemic vasculitis include a questionnaire as well as clinical and laboratory parameters. This approach yields good sensitivity and sensibility but it remains to be formally validated.

\section{Pathogenesis of HCV-induced MC}

For many years, an infectious agent was thought to be the etiologic factor underlying MC. This hypothesis gained significant support from the study of Meltzer and Franklin [18], in which the pathogenetic role of a hepatotropic virus was suggested. Levo et al. [49] proposed hepatitis $B$ virus as the causative agent but this was ruled out because HBV viremia was rarely observed in MC patients and anti-HBV antibody expression varies widely among different MC populations. Currently, $\mathrm{HBV}$ is considered as a causative agent of MC only in about $5 \%$ of cases [50].

In the early 1990s, after the identification of HCV as the major etiologic agent of non-A, non$\mathrm{B}$ hepatitis, several authors reported the high prevalence of anti-HCV antibodies in MC patients $[9,51]$. This correlation was subsequently confirmed by the detection of HCV genomic sequences, especially in the cryoprecipitates versus the corresponding supernatants [10]. In 
addition, HCV-related proteins were demonstrated in the liver, skin, and kidneys of MC patients $[29,38]$ as well as in their lymph nodes and circulating CD34+ hematopoietic progenitor cells $[52,53]$.

The intrinsic mechanism by which HCV promotes cryoglobulin production remains unclear. Viral persistence may provide a continuous stimulus for the host immune system, which is unable to synthesize neutralizing antibodies [54, 55]. According to this scheme, cryoglobulins may be considered the result of these interactions and the presence of $\operatorname{IgM}$ molecules with RF activity a crucial event in the cryoprecipitating process [12]. These IgM molecules are almost always associated with light chain 17.109 and heavy chain G6 [56] cross-idiotypes, considered to be the product of a restricted expression of germline genes [24]. In the course of chronic HCV infection, the IgM-17.109 RF immune complexes bind anti-HCV IgG [57]. Among viral antigens, core protein plays a crucial role in cryoglobulin formation as it is the relevant ligand for IgG (Figure 2) [39].

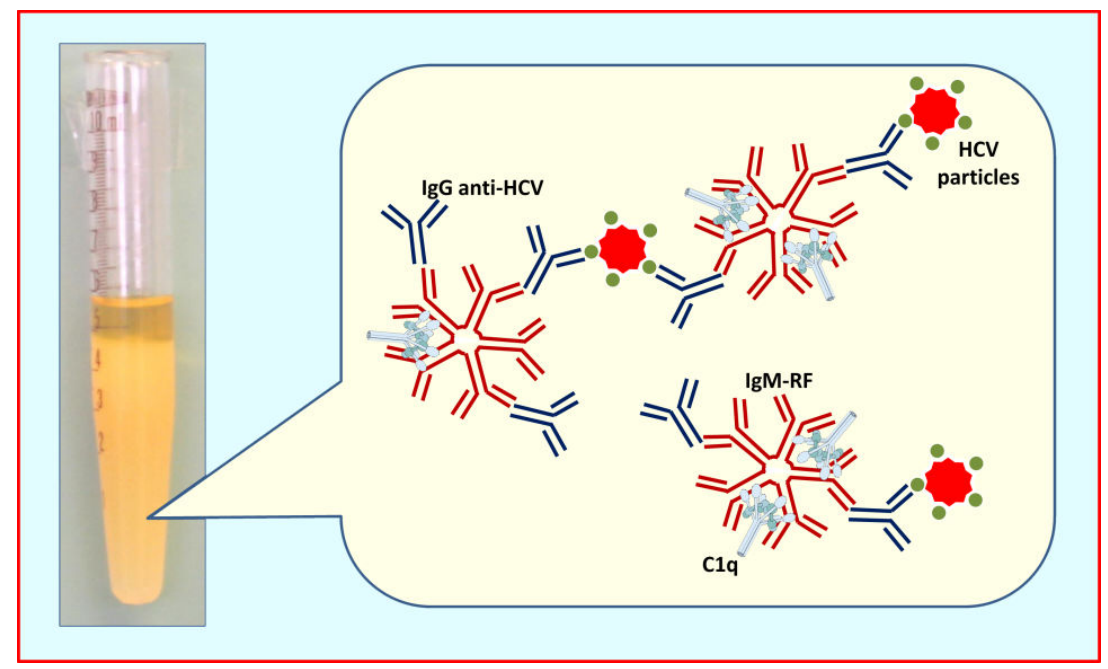

Figure 2. Serum cryoprecipitation at low temperature $\left(+4^{\circ} \mathrm{C}\right)$ in a Wintrobe's tube. Cryoprecipitating immune complexes are typified by IgM-RF, which binds IgG with anti-HCV specificity. Of crucial importance is the role of complement fractions such as C1q.

The interaction between HCV and lymphocytes results in the modulation of cell functions. In particular, the in vivo activation and expansion of CD5-positive B cells is considered the major source of IgM RF molecules in type III MC $[58,59]$. It has been postulated that the initial activation of these cells is followed by the emergence of a dominant clone that synthesizes a monoclonal RF, resulting in the development of type II MC after a transition phase in which an IgM clonal heterogeneity reflects a type II-type III variant [22]. In the peripheral blood of a subset of $\mathrm{HCV}$-positive patients with $\mathrm{MC}$, a clonal expansion of $\mathrm{IgM}^{+} \mathrm{CD} 27^{+} \mathrm{B}$ cells expressing hyper-mutated RF-like Ig has been demonstrated in association with $\mathrm{V}_{\mathrm{H}} 1-69 / \mathrm{J}_{\mathrm{H}} 4$ and $\mathrm{V}_{\mathrm{H}} 3-20$ 
gene segment restriction [60]. These findings have been interpreted as a B-cell proliferation induced by specific antigen stimulation, thus sustaining the notion that persistent B-cell stimulation is a first step in the malignant evolution of MC [61].

An important role in the nature of cryoprecipitating immune complexes is played by the complement system. Generally, complement binding reduces the size of immune complexes, thus maintaining them in solution [62]. In the sera of MC patients, two different compartments can be identified in which C3 and C4 fractions are present in larger amounts in the soluble phase but are barely detectable in cryoprecipitates [12]. By contrast, C1q protein and C1q binding activity are significantly enriched in cryoprecipitates [39]. These data support the hypothesis that an efficient engagement of $\mathrm{C} 1 \mathrm{q}$ protein by cryoglobulins is a crucial factor in the pathogenesis of MC (Figure 2).

The receptor for the globular domain of $\mathrm{C} 1 \mathrm{q}(\mathrm{gC} 1 \mathrm{q}-\mathrm{R})$ directly interacts with $\mathrm{HCV}$ core protein, thereby altering host T- and B-cell immunity. Specifically, the gC1q-R/HCV core protein interaction has been shown to modulate T-cell immune responses whereas circulating $\mathrm{HCV}$ core protein engagement with gC1q-R expressed on the surface of B-lymphocytes allows the virus to directly affect host immunity [63-65]. The widespread expression of gC1q-R on the surface of circulating blood immunocytes and endothelial cells may determine specific binding to $\mathrm{HCV}$ core protein containing immune complexes. Moreover, it was recently demonstrated that higher levels of soluble gC1q-R reflect a higher specific mRNA expression by the blood mononuclear cells of MC patients [66]. Soluble gC1q-R was shown to circulate as a complexed form containing both $\mathrm{C} 1 \mathrm{q}$ and $\mathrm{HCV}$ core protein binding to two different sites of the molecule.

Serum C4d protein levels were found to be lower in MC patients than in either chronic HCV carriers or healthy subjects [66]. C4d is a low molecular weight fragment derived from the cleavage of $\mathrm{C} 4$ complement fraction as part of the classical pathway of complement activation. Deposits of the protein are present in almost all skin biopsy samples of patients with cryoglobulinemic vasculitis, suggesting that low circulating C4d levels are derived from sequestered fragments in the vascular bed.

$\mathrm{HCV}$ core protein, in the presence of high levels of circulating gC1q-R, can exacerbate the inflammatory state by activating the complement cascade, thus determining endothelial cell activation and initiating an in situ inflammatory response. From a biological point of view, the clinical response to antiviral therapy consists of a significant reduction in soluble gC1q- $\mathrm{R}$ in association with increased levels of $\mathrm{C} 4 \mathrm{~d}$ and a lower viral load [66].

\section{Clinical outcome}

Cryoglobulinemic syndrome (CS) is a systemic vasculitis that changes the clinical outcome of $\mathrm{HCV}$-infected patients but its long-term impact on the course of $\mathrm{HCV}$ infection has not been assessed. In 2004, Ferri et al. reported a significantly lower cumulative 10-year survival from the time of diagnosis in their series of 231 cryoglobulinemic patients age and sex-matched with individuals from the general population [41]. Other factors recognized as associated with a poor prognosis are renal involvement, widespread vasculitis, and infectious processes [67, 68]. 
Recently, we completed a prospective study of a cohort of 950 chronically HCV-infected patients who were referred to our department over a period of about 15 years starting from 1990. MC was determined in 246 patients (28\%), 184 (74.8\%) of whom also had cryoglobulinemic vasculitis. The rate of progression of liver fibrosis was lower in patients with CS than in those without but the probability of developing cirrhosis and hepatocellular carcinoma was higher in the latter group ( $24.9 \%$ vs. $14.2 \%$, p $<0.005$ and $20.3 \%$ vs. $7.5 \%, p=0.003$, respectively). Extrahepatic complications such as renal failure, neurological impairment, and the evolution to a B-cell malignancy were more frequent in patients with CS than in those without $(32.6 \%$ vs. $3 \%, p<0.0001 ; 31.2 \%$ vs. $4.8 \%, p<0.0001$ and $15 \%$ vs. $7.1 \%, p=0.003$, respectively; unpublished data, manuscript submitted). However, the 15-year survival rate was similar in HCVinfected patients with or without CS, despite differences in morbidity and causes of death (70.2\% vs. $71.7 \%)$.

\section{Therapy}

In the pre-HCV era, the management of MC was conventionally based on the use of corticosteroids and immunosuppressive drugs such as cyclophosphamide, with the aim of preventing irreversible organ failure, reducing pain, and improving patients' quality of life. In 1987, recombinant IFN- $\alpha$ was empirically tested in seven patients with "essential" MC [69]. With the subsequent demonstration of the pathogenetic role of HCV [11], IFN- $\alpha$ became a rational therapeutic strategy. The introduction of pegylated IFN- $\alpha$ and subsequently of ribavirin changed the therapeutic scenario for chronic hepatitis $C$, by increasing the virological response [70-72]. This combination was shown to also be remarkably effective in HCV-related MC, resulting in a complete clinical response and a sustained virological response (SVR) in $78 \%$ of the patients [73]. In addition, serum levels of C3 and C4 complement fractions normalized in $80 \%$ of the treated patients and cryoglobulins disappeared in $56 \%$. However, even if antiviral treatment results in a resolution of the vasculitis, for patients with neuropathy or glomerulonephritis there is no or only partial improvement, suggesting that the clinical outcome is conditioned by factors other than the virus [12].

Extra-hepatic manifestations of chronic HCV infection such as MC are characterized by B-cell clonal expansions (including RF-synthesizing B-cells) [12, 74-76], which have been demonstrated in at least three different compartments, namely, liver, bone marrow, and the circulation. Consequently, the deletion of B-cell clonalities may provide a further approach to the treatment of MC. It is well known that CD20 antigen, a transmembrane protein, is selectively expressed on pre-B and mature lymphocytes and that CD20-positive cells are greatly expanded and activated in patients with MC $[77,78]$.

On the basis of the demonstrated effectiveness of Rituximab (RTX), a chimeric monoclonal antibody specifically directed at CD20 antigen, in autoimmune and lymphoproliferative disorders [79-81], its use seemed logical in the treatment of HCV-related MC in patients refractory to, or relapsing after, conventional antiviral therapy. Indeed, RTX was shown to be effective, safe, and well tolerated in MC patients, both in those resistant to previous treatments 
and in those with recurrent disease $[82,83]$. Thus, several papers subsequently addressed the issue of using RTX in this setting, either alone or in combination with steroids [84, 85].

Since an increased viremia has been frequently reported in responsive patients, we proposed a triple therapeutic approach (pIFN- $\alpha$ plus RBV plus RTX), designated with the acronym PIRR [86]. This drug combination was administered to $22 \mathrm{HCV}$-positive MC patients whereas 15 additional patients with the same pathology received PIFN- $\alpha$ plus RBV with the exclusion of RTX. All patients were followed for 36 months from the end of treatment. A complete response was determined in $54.5 \%$ of the patients treated with PIRR, but in only $33.3 \%$ of those on PIFN$\alpha$ plus RBV without RTX ( $\mathrm{p}<0.05)$. Even more interesting were the observations that: $a)$ in the large majority $(83.3 \%)$ of the responders in the PIRR-treated group, B-cell populations in the liver, bone marrow, and peripheral blood compartments underwent a conversion from oligoclonal to polyclonal; b) CR was maintained in all patients in the PIRR group throughout the follow-up period whereas this was the case in only $40 \%$ of those in the control group. However, whether RTX should be administered to patients with cryoglobulinemic vasculitis as first- or second-line therapy remains to be established [87].

Of particular interest are MC patients who do not achieve a SVR and those in whom there is continuous cryoglobulin production despite viral eradication. In the former, the use of the new direct-acting antivirals (DAAs) such as Telaprevir or Boceprevir (recently approved by the FDA for the treatment of HCV genotype 1 chronic infection) may offer a further therapeutic option [88]. The persistence of MC vasculitis in patients achieving a SVR represents an emerging picture following antiviral and B-cell-depleting combined therapies [89, 90]. In these patients differences in the immunochemical structure of circulating immune-complexes may be postulated and the use of corticosteroids, cyclophosphamide, RTX, or novel anti-CD20 monoclonal antibodies such as Ofatumomab may be considered as alternative therapeutic options [91]. Therapeutic apheresis is a palliative procedure that can be extremely useful for the treatment of severe, life-threatening vasculitis [87] as well as for chronic leg ulcers in patients resistant to other therapies [92].

Additional therapeutic approaches to $\mathrm{MC}$, including the tyrosine kinase inhibitor imatinib and anti-angiogenic drugs such as thalidomide, bortezomib (a proteasome inhibitor), and IL-2 have been proposed but their therapeutic effectiveness in patients with MC remains to be determined in controlled studies $[93,94]$.

\section{HCV infection and malignant lymphoproliferation}

About $15 \%$ of all human tumors are of viral origin. The percentage of virus-related cancer is three-fold higher in developing than in developed countries, reflecting the higher prevalence of infection with oncogenic viruses rather than exposure to tumor-enhancing co-factors [95]. The pathogenetic role of some viruses in human tumors has been clearly described. This is the case for Epstein-Barr virus (EBV), which is etiologically linked to Burkitt's lymphoma and probably other tumors [96]. Other such viruses include human papillomavirus (HPV), associated with cervical, ano-genital, skin and head and neck cancers [97]; human T-cell 
leukemia virus type 1 (HTLV-1), which causes adult T-cell leukemia [98]; and human herpes virus type 8 (HHV-8), which may be involved in Kaposi's sarcoma, primary effusion lymphoma, and multicentric Castelman's disease [99].

Among hepatotropic viruses, the role of both hepatitis B (HBV) and hepatitis C (HCV) viruses in the etiopathogenesis of hepatocellular carcinoma (HCC) is well defined, although HBV and $\mathrm{HCV}$-induced cancerogenesis proceeds by quite different mechanisms. For HCV, initial observations regarding the causative association between infection with the virus and NHL [100] were subsequently confirmed in a large number of studies [101, 102]. In a meta-analysis evaluating 15 studies [103], the relative risk (RR) of all NHL among HCV-positive patients was 2.5 , with a 95\% confidence interval (CI) considering case control studies, and a RR of 2.0 (95\% $\mathrm{CI}$ ) in cohort studies. Early studies reported the prevalence of extranodal NHLs and histotypes such as lymphoplasmacytic lymphomas in HCV-positive patients. These findings can be ascribed to the occurrence of malignant lymphomas in HCV-positive patients with other lowgrade lymphoproliferative disorders such as MC (Figure 3) [104].
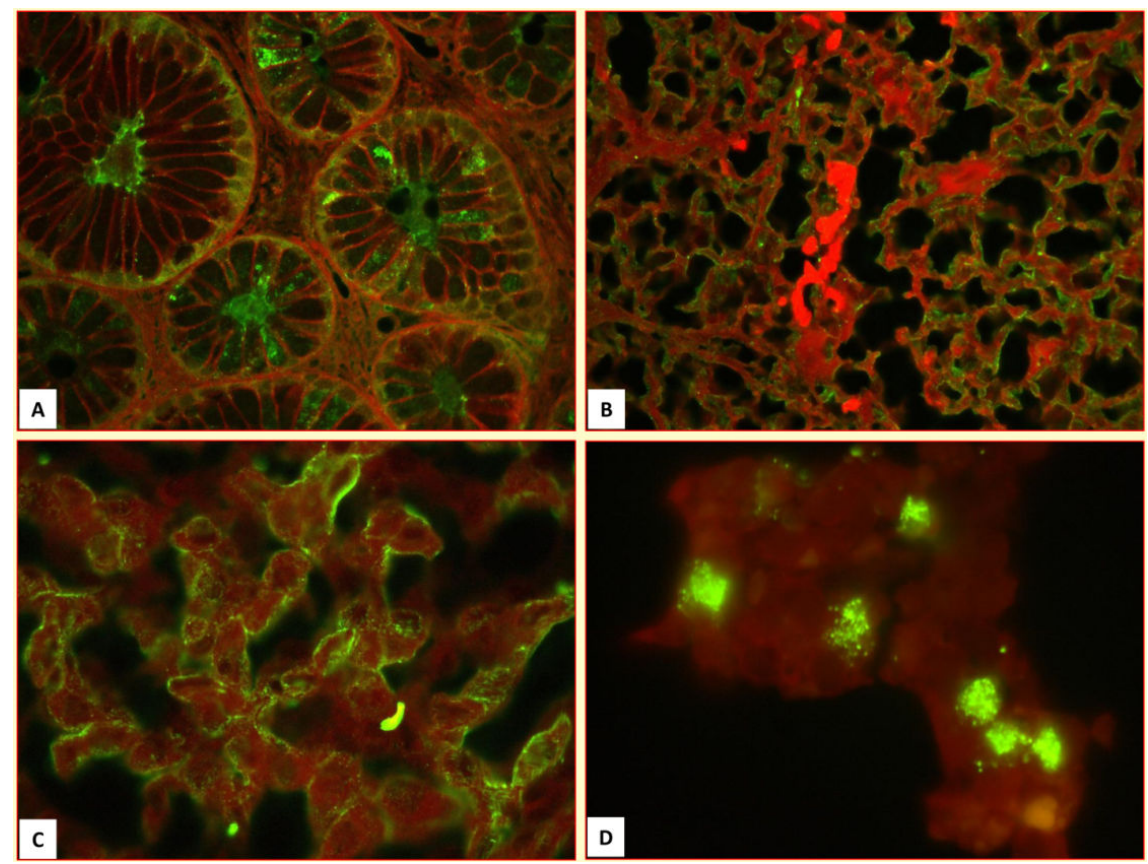

Figure 3. Demonstration of HCV E2 protein by immunofluorescence in the neoplastic B-cells of mucosa-associated lymphoid tissue (MALT)-like gastric lymphoma (A), a neoplastic lymph node (B), splenic lymphoma (C) and bone marrow infiltrates $(D)$.

Currently, there are no clear differences concerning the association between HCV and major histologic B-cell NHL subtypes such as diffuse large B-cell (DLBC), follicular, marginal zone, and chronic lymphocytic leukemia/small lymphocytic lymphomas [105]. However, lymphoma 
subtypes that do not originate from germinal center or post-germinal center B-cells, such as mantle cell (MC)-NHL, Burkitt's lymphoma, T-cell lymphoma, and Hodgkin's lymphoma, have not been consistently linked to HCV infection [106]. This finding is in line with the notion that the proliferation of specific B-cell clones following chronic antigenic stimulation is the mechanism that drives the determination of NHL subtypes.

\section{Clinical and histopathological features of HCV-associated NHLs}

As previously stated, both clinical and biological observations strongly suggest a role for $\mathrm{HCV}$ in a variety of extrahepatic disorders, including dermatologic, hematologic, endocrinologic, and autoimmune diseases. Of interest here is the striking association between HCV infection and $\mathrm{MC}$, which has been convincingly demonstrated. However, MC can also develop as an indolent B-cell lymphoproliferative disorder, with a potentially malignant evolution [12]. In a long-term analysis, progression to NHL was demonstrated in 5-10\% of $\mathrm{HCV}$-infected patients. Symptoms indicative of progression are usually mild and comprise an expanding spectrum of autoimmune phenomena, including hemolytic anemia, thrombocytopenia, and granulocytopenia [107-109].

It has been calculated that about $13 \%$ of patients with B-NHLs are HCV-positive [110] and that about $10 \%$ of patients with HCV-associated MC will develop a B-NHL within the following ten years [111]. Two different subsets of HCV-associated B-cell NHLs can be distinguished, presenting as distinct clinical and pathological entities. The first is a low-grade NHL evolving from $\mathrm{MC}$, with possible bone marrow involvement and further evolution into an aggressive phenotype. The second is an aggressive NHL without an underlying MC and with bone marrow involvement [100, 107].

A peculiar feature of $\mathrm{HCV}$-associated lymphomas is the extranodal involvement, with the liver, salivary glands, bone marrow, and spleen most often affected [112]. The most common histotypes are marginal zone lymphomas, lymphoplasmacytic lymphomas, and DLBC lymphomas [113]. Splenic marginal zone lymphoma in particular seems to have a high prevalence in $\mathrm{HCV}$-infected patients with MC [114]. In addition, follicular and MC lymphomas may also be associated with HCV infection [113], as can MALT lymphoma, in which HCV is detected in about $35 \%$ of the non-gastric forms of these tumors [115].

\section{Pathogenesis of HCV-associated NHLs}

The chronic persistence of HCV provides a continuous stimulus for the host immune system sustaining B-cell clonal expansions [15]. Thus, the monoclonal IgM RF synthesis that characterizes MC can be ascribed to the expression of one such single dominant clone [22, 59]. Accordingly, the capacity of HCV to directly modulate B- and T-cell function [116] can be considered as one of the necessary criteria needed to define HCV as an etiologic factor in lymphomagenesis. 
Among the different cell-surface receptors that have been described as possible binding sites for HCV [117, 118], the most well-studied is CD81, a tetraspanin present on the surface of Blymphocytes (Figure 4) [119].

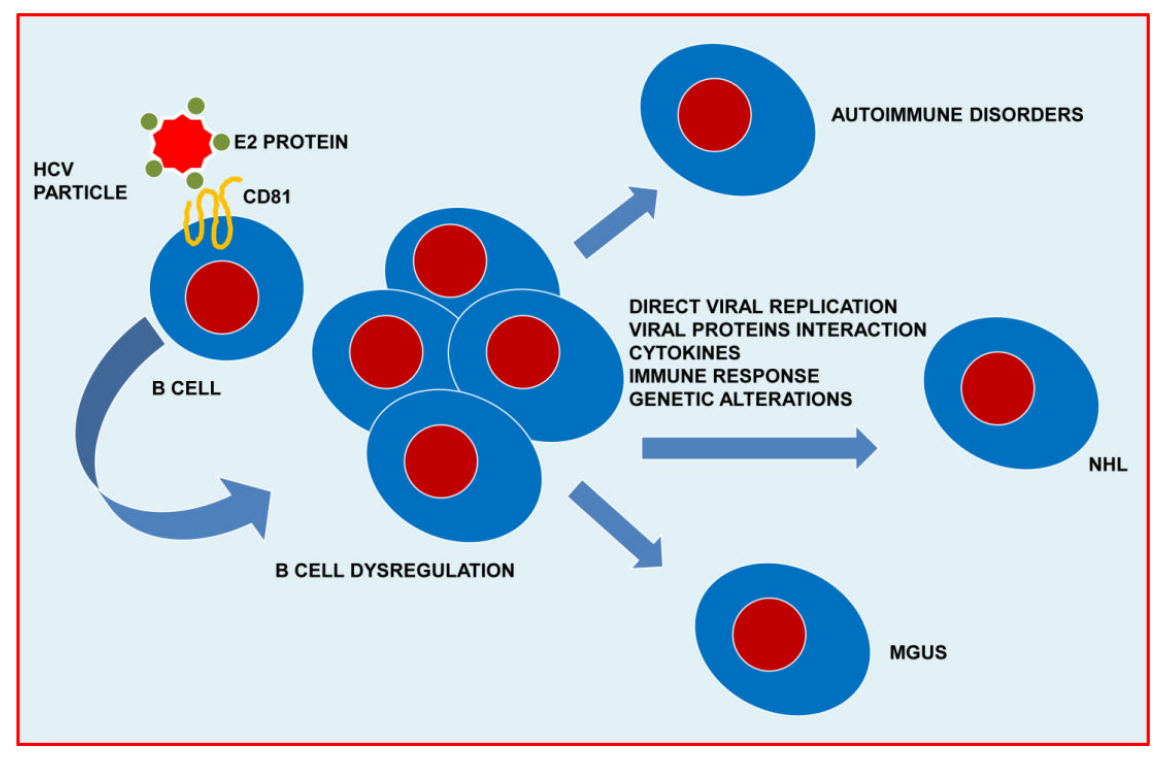

Figure 4. Schematic representation of the interactions between HCV and B cells. CD81, which binds E2 protein, is the best-studied cellular receptor. Active HCV replication in B-lymphocytes, in addition to continuous stimulation of the host immune system, may lead to a "B-cell deregulation," which eventually gives rise to oligo/monoclonal expansions. Clinical evolution into autoimmune disease or monoclonal gammopathy of undetermined significance (MGUS) as well as frank lymphoma may be conditioned by other factors, either alone or in combination, e.g., active viral replication, viral protein interactions, cytokines, the host immune response, and genetic factors.

Interestingly, a higher cell-associated viral load due to the enrichment of HCV RNA in circulating lymphocytes has been demonstrated in cryoglobulinemic patients [77] and appears to reflect either a higher receptor density on the cell surface or the polymorphism of receptor genes [120-122].

In addition, a direct stimulus for lymphocyte proliferation can be provided by direct infection with HCV and active replication of the virus inside B-cells [123], further evidence that HCV is an oncogenic virus. Since HCV is a single-stranded RNA virus with an RNA-dependent RNA polymerase, detection of the viral RNA minus strand is the only molecular marker of an active viral replication whereas detection of the plus strand RNA may be the result of passive cellular contamination by circulating virions. A direct correlation between active HCV infection of B cells and MC was established using a highly specific and sensitive method for HCV RNA minus strand detection [124]. These results demonstrated the lymphotropism of $\mathrm{HCV}$, in which peripheral blood lymphocytes are another productive compartment of $\mathrm{HCV}$ infection in addition to serving as a circulating reservoir of the virus (Figure 4) [125]. 
A distinguishing feature seen in cryoglobulinemic patients is the presence of clonally expanded, RF-synthesizing B-cells [126]. By means of PCR amplification techniques, immunoglobulin variable region $(\mathrm{IgV})$ genomic sequences, as a molecular marker of B cell progeny, were analyzed, providing evidence of an antigen-driven B cell clonal expansion. Heavy- and lightchain $\operatorname{IgV}$ gene analysis indicated a high mutation rate as usually occurs from a germinal or post-germinal center origin [127]. Little is known about the viral antigens capable of inducing this clonal expansion and no viral protein identified thus far seems to be a specific ligand for the B-cell receptor [128]. All expanded B-cell clones characterized by the somatic hypermutation of $\mathrm{IgV}$ genes seem capable of recognizing a single epitope, suggesting that they arise from a pool of cells selected for non-self antigens, probably in the course of a germinal center reaction [127]. Interestingly, many expanded B-cell clones display a complementarity determining region-3 (CDR-3) resembling CDR-3 of rheumatoid factor (RF CDR-3), suggesting that they derive from autoimmune-oriented precursors with anti-IgG specificity.

B-cell proliferation is characterized by a continuous rearrangement of $\operatorname{IgV}$ genes that gives rise to different mutants. PCR amplification of the VDJ region identifies the unique combinations of $\mathrm{N}$ regions with $\mathrm{DH}$ and $\mathrm{JH}$ regions that can be considered as a clonal marker of cellular progeny. This method was used to show that B-cell clonal expansions are present in the liver tissue, rather than in the blood and bone marrow compartments, of almost $90 \%$ of HCVpositive MC patients [126]. The detection of inflammatory infiltrates of the portal tracts resembling follicle-like structures with a functionally active germinal center is a diagnostic feature of liver biopsies from patients chronically infected with HCV [129, 130]. In addition, the VDJ patterns determined in these patients show oligoclonality or monoclonality, thus demonstrating that intrahepatic B cell expansions derive from a few cells or a single cell; morevoer, each focus may derive from a different B-cell, resulting in the development of unrelated clones [129, 130].

Intrahepatic B-cell clonal expansions are almost invariably associated with extrahepatic manifestations such as MC, high serum levels of RF activity, monoclonal gammopathy of undetermined significance, and B-cell malignancy. Sequence analyses of the IgH CDR-3 gene segments of intraportal B-cell clonalities revealed a wide range of variations, suggesting that they are also the result of an antigen-driven response [131]. Accordingly, it can be inferred that B-cell clones begin to expand in the liver as the result of an IgH-VDJ upregulated mutational activity, with subsequent migration of the cells to the peripheral blood and bone marrow [74].

Given that the liver is not only the primary target of HCV infection but also the main site of inflammation, B-cell recruitment and expansion, identification of the factor(s) contributing to the establishment and progression of this complex clinical spectrum is of crucial importance. In this context, research focused on the molecules capable of prolonging B-cell survival is particularly relevant. Among the compounds identified thus far, B-cell activating factor (BAFF), a chemokine belonging to the tumor necrosis factor (TNF) family, seems to play an important role in B-cell survival [30]. The most important effect of BAFF is probably the inhibition of B-cell apoptosis. BAFF expression was shown to be higher in the intraportal lymphoid aggregates and skin tissue of cryoglobulinemic patients. Synthesis is thought to start in inflammatory sites such as the liver and skin and then arise the circle [132]. 
One of the most important anti-apoptotic factors is $\mathrm{Bcl}-2$ protein. Its upregulation due to $\mathrm{t}(14$; 18) chromosomal translocation, is a specific feature of follicular B-NHLs and it also has been described in cryoglobulinemic patients [133]. However, in an our previous study, Bcl-2/IgH amplification was not detected in intraportal inflammatory infiltrates isolated from HCVpositive patients by means of laser microdissection of liver biopsy tissue [134], suggesting that heavy chain Ig gene rearrangement is not associated with $\mathrm{Bcl}-2 / \mathrm{IgH}$ chromosomal translocation in the liver compartment. This discrepancy could reflect ethnic and/or environmental factors in that $\mathrm{Bcl}-2 / \mathrm{IgH}$ rearrangement is less common in the Mediterranean region than in northern Europe [134]. Alternatively, in non-neoplastic conditions such as $\mathrm{MC}, \mathrm{Bcl}-2 / \mathrm{IgH}$ rearrangement could be a transient effect due to the persistence of viral infection [134].

Activation-induced cytidine deaminase (AID) is an enzyme involved in the degradation of pyrimidine nucleotides. It is also essential for somatic hypermutation and class-switching recombination of immunoglobulin genes in B-cells [135]. Some studies have proposed a pathogenetic role of AID in B-cell lymphomagenesis, in particular during the initiation and progression of B-NHL because a deregulation in either of these two processes can determine a chromosomal translocation and/or an aberrant somatic hypermutation, two of the main causes of B-NHL-associated genetic accidents [136, 137]. It has been postulated that AID is triggered by HCV core protein in human hepatocytes via NFkB activation (Figure 5) [138].

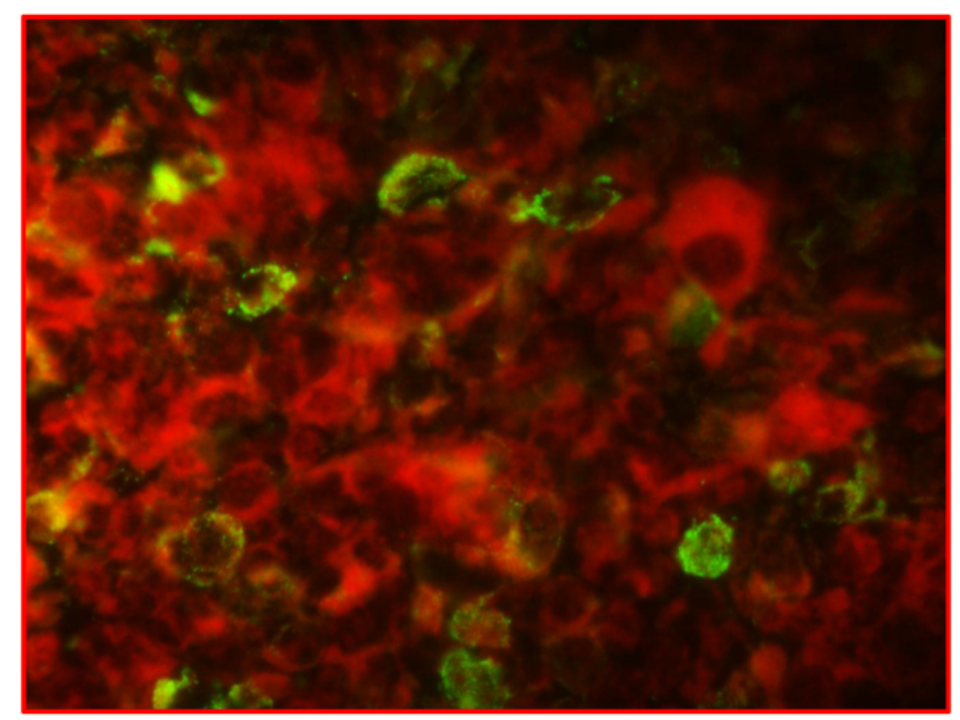

Figure 5. Detection of activation-induced cytidine deaminase (AID) protein in the lymph node of a patient with HCVassociated B-cell NHL.

Together, these data support epidemiological observations of an association between HCV chronic infection and B-NHL. Nonetheless, further studies will be necessary to better evaluate the pathogenetic mechanisms and optimize the therapeutic approaches. 


\section{HCV related NHLs: Therapeutic opportunities}

As previously described, $\mathrm{HCV}$ chronic infection may well be a risk factor for the development of "indolent" lymphoproliferative disease such as MC as well as for frank B-cell NHL, albeit with a wide geographical variability.

The induction of a SVR following an effective antiviral therapy with pegylated interferon plus ribavirin should exert a preventive effect on lymphomagenesis in patients chronically infected with HCV [139]. In addition, based on the observation of gastric MALT lymphoma regression after the eradication of $H$. pylori infection, antiviral therapy should induce the regression of NHL.

The efficacy of antiviral therapy was described by Hermine et al. [140] in patients with villous lymphocytes splenic lymphoma, with complete remission achieved in eight of the nine HCVpositive patients. Further studies confirmed these data. In a systematic review by Gisbert et al. [141], about $75 \%$ of $\mathrm{HCV}$-infected patients with a lymphoproliferative disorder achieved a complete remission following antiviral treatment.

Recently, Arcaini et al. assessed the role of antiviral therapy in HCV-associated indolent B-cell lymphomas [142]. According to the WHO classification, indolent lymphomas are poorly symptomatic diseases belonging to low-grade lymphoma [143]. They include follicular lymphoma, small lymphocytic lymphoma, marginal zone lymphomas, splenic marginal zone lymphoma, primary nodal marginal zone lymphoma, extranodal marginal zone lymphoma of mucosa-associated tissue (MALT), and lymphoplasmacytic lymphoma. In almost all such patients a hematologic response was obtained subsequent to the virological response, reinforcing the evidence for a causative link between HCV and lymphomas [142]. Further studies will be necessary to establish the efficacy of novel direct antiviral agents, such as boceprevir and telaprevir, which increase SVR rates in genotype $1 \mathrm{HCV}$ infection while also increasing the hematologic response rate of patients with more resistant infection. On the basis of therapeutic regimens for $\mathrm{HCV}$-associated MC that consist of a combination of RTX and antiviral therapy $[86,144]$ a similar approach may be successful also in HCV patients with indolent B-cell lymphomas.

The use of antiviral therapy in patients with HCV-positive aggressive B-cell lymphomas such as DLBC and mantle cell lymphomas appears to be less effective. This lack of a response may be related to the antigen-independent phase of lymphomagenesis, in which malignant evolution occurs irrespective of viral persistence. These lymphomas require an adequate chemotherapy with or without RTX, even if the development of hepatitis flares has been described [145]. However, there are also some papers showing a clinical remission of DLBCL [146] and mantle cell lymphoma [147] after antiviral therapy. While a combination of antiviral therapy and immunochemotherapy has been proposed to prevent or treat hepatitis flares [148], combination therapy consisting of interferon plus ribavirin usually results in an increased hematologic toxicity, as previously reported [149]. A more interesting strategy may be a sequential schedule consisting of immune-chemotherapy followed by pegylated interferon plus ribavirin. The aim is to induce a SVR in patients obtaining a complete remission of their 
lymphoma after chemotherapy, in order to prevent hepatitis reactivation and to achieve longterm control of their NHL [150], effectively and with good tolerance. However, this approach needs further validation in larger prospective studies.

\section{Conclusions}

HCV infection should not be considered as a major cause only of liver disease; instead, several different biological compartments are involved. In particular, B-lymphocytes are an important site in which HCV may actively replicate, thereby serving as a viral reservoir.

Viral persistence represents a continuous stimulus for the host immune system, leading to Bcell selection and clonal expansion as evidenced by the synthesis of IgM autoantibodies with RF activity (IgM-RF), which characterizes MC. This process seems to occur in a microenvironment such as that provided by intraportal lymphoid follicles due to distinct selection events probably supported by cytokine signaling, thereby sustaining B-cell activation and proliferation. The unique clinical features of $M C$ are the result of the biological activities of the immune complexes constituted by IgM-RF, anti-HCV IgG, viral antigens, and complement fractions. Of particular interest is the role played by $\mathrm{C} 1 \mathrm{q}$ and the globular domain of the $\mathrm{C} 1 \mathrm{q}$ receptor (gC1q-R), which, in combination with viral proteins such as core protein, modulates immune complex deposition in the vascular bed, leading to cryoglobulinemic vasculitis. The involvement of viral proteins also has been suggested for B-cell proliferation.

Thus, MC may be considered a low-grade, indolent, benign lymphoproliferative disease reflecting an antigen-dependent B-cell clonal expansion with potential evolution into a malignant phenotype. HCV-related malignant NHLs may accordingly derive from a benign lymphoproliferation such as MC and usually occur as low grade/indolent lymphomas but, over time, their phenotypes may become more aggressive. Alternatively, they may arise directly, often involving extranodal sites, with an indolent phenotype similar to that of MALT lymphomas or as highly aggressive lymphomas.

The definition of $\mathrm{HCV}$ as an etiologic agent in both benign and malignant lymphoproliferations suggests the efficacy of antiviral therapy both in MC and in NHLs. The combination of antiviral therapy with B-cell depletion, with its ability to induce long-term clinical, immunologic, and virologic remission, may be considered the standard of care for cryoglobulinemic vasculitis. In addition, a clinical remission of low-grade NHLs after antiviral treatments has also been described. These results confirm the pathogenetic role of HCV in lymphoproliferative diseases and offer new therapeutic options even if further studies are mandatory. Antiviral therapy may also have a role in high grade NHLs in which the pathogenetic process can be considered antigen-independent. In these patients, who require immune-chemotherapy, antiviral treatment may be useful in preventing hepatitis flares as well as NHL relapse if a SVR is obtained.

In conclusion, $\mathrm{HCV}$ infection should be considered a multifaceted disease, with a potentially malignant evolution involving not only the liver compartment (i.e., hepatocellular carcinoma), 
but also other targets, such as lymphoid tissue. However, there are several further aspects that need to be clarified regarding the pathogenetic mechanisms of HCV-induced lymphomagenesis. In this regard, an evaluation of the impact of new direct antiviral agents as well as novel target-therapies inducing B-cell depletion will be of great interest in the prevention of HCVrelated malignancies.

\section{Acknowledgements}

This article was made possible by the support and assistance of Dr. Vincenza Conteduca, Dr. Sabino Russi, Mr. Vito De Gennaro, Dr. Fabio Pavone, and Dr. Ida Sebastiani.

Funding was provided by the University of Bari and AIFA (Agenzia Italiana del Farmaco, funds for independent studies, 2007, contract no. FARM7SJX)

\section{Author details}

Gianfranco Lauletta

Address all correspondence to: gianfranco.lauletta@uniba.it

Department of Biomedical Sciences and Human Oncology, Section of Internal Medicine and Clinical Oncology,Liver Unit, University of Bari Medical School, Bari, Italy

\section{References}

[1] Choo QL, Richman KH, Han JH, Berger K, Lee C, Dong C, et al. Genetic organization and diversity of the hepatitis C virus. Proc Natl Acad Sci U S A 1991;88(6) 2451-2455.

[2] Hoofnagle JH. Course and outcome of hepatitis C. Hepatology 2002;36(5 Suppl 1) S21-29.

[3] Pavlovic D, Neville DC, Argaud O, Blumberg B, Dwek RA, Fischer WB, et al. The hepatitis $C$ virus $\mathrm{p} 7$ protein forms an ion channel that is inhibited by long-alkyl-chain iminosugar derivatives. Proc Natl Acad Sci U S A 2003;100(10) 6104-6108.

[4] Rosenberg S. Recent advances in the molecular biology of hepatitis C virus. J Mol Biol 2001;313(3) 451-464.

[5] Lohmann V, Hoffmann S, Herian U, Penin F, Bartenschlager R. Viral and cellular determinants of hepatitis C virus RNA replication in cell culture. J Virol 2003;77(5) 3007-3019. 
[6] Heller T, Saito S, Auerbach J, Williams T, Moreen TR, Jazwinski A, et al. An in vitro model of hepatitis C virion production. Proc Natl Acad Sci U S A 2005;102(7) 2579-2583.

[7] Dammacco F, Sansonno D. Antibodies to hepatitis C virus in essential mixed cryoglobulinaemia. Clin Exp Immunol 1992;87(3) 352-356.

[8] Ferri C, Greco F, Longombardo G, Palla P, Moretti A, Marzo E, et al. Antibodies to hepatitis $C$ virus in patients with mixed cryoglobulinemia. Arthritis Rheum 1991;34(12) 1606-1610.

[9] Agnello V, Chung RT, Kaplan LM. A role for hepatitis C virus infection in type II cryoglobulinemia. N Engl J Med 1992;327(21) 1490-1495.

[10] Dammacco F, Sansonno D, Cornacchiulo V, Mennuni C, Carbone R, Lauletta G, et al. Hepatitis $C$ virus infection and mixed cryoglobulinemia: a striking association. Int J Clin Lab Res 1993;23(1) 45-49.

[11] Dammacco F, Sansonno D, Piccoli C, Tucci FA, Racanelli V. The cryoglobulins: an overview. Eur J Clin Invest 2001;31(7) 628-638.

[12] Sansonno D, Dammacco F. Hepatitis C virus, cryoglobulinaemia, and vasculitis: immune complex relations. Lancet Infect Dis 2005;5(4) 227-236.

[13] Sansonno D, Carbone A, De Re V, Dammacco F. Hepatitis C virus infection, cryoglobulinaemia, and beyond. Rheumatology (Oxford) 2007;46(4) 572-578.

[14] Agnello V. The aetiology of mixed cryoglobulinaemia associated with hepatitis C virus infection. Scand J Immunol 1995;42(2) 179-184.

[15] Dammacco F, Sansonno D, Piccoli C, Racanelli V, D'Amore FP, Lauletta G. The lymphoid system in hepatitis $C$ virus infection: autoimmunity, mixed cryoglobulinemia, and Overt B-cell malignancy. Semin Liver Dis 2000;20(2) 143-157.

[16] Wintrobe MM, Buell MV. Hyperproteinemia associated with multiple myeloma. Bull Johns Hopkins Hosp 1933;52(10.

[17] Lerner AB, Watson CJ. Studies of cryoglobulins; unusual purpura associated with the presence of a high concentration of cryoglobulin (cold precipitable serum globulin). Am J Med Sci 1947;214(4) 410-415.

[18] Meltzer M, Franklin EC. Cryoglobulinemia--a study of twenty-nine patients. I. IgG and IgM cryoglobulins and factors affecting cryoprecipitability. Am J Med 1966;40(6) 828-836.

[19] Brouet JC, Clauvel JP, Danon F, Klein M, Seligmann M. Biologic and clinical significance of cryoglobulins. A report of 86 cases. Am J Med 1974;57(5) 775-788.

[20] Denman AM. Cryoglobulins and the immunopathological manifestations of autoimmune disease. Clin Exp Immunol 1992;87(2) 169-171. 
[21] Wang AC, Wells JV, Fudenberg HH. Chemical analyses of cryoglobulins. Immunochemistry 1974;11(7) 341-345.

[22] Tissot JD, Schifferli JA, Hochstrasser DF, Pasquali C, Spertini F, Clement F, et al. Two-dimensional polyacrylamide gel electrophoresis analysis of cryoglobulins and identification of an IgM-associated peptide. J Immunol Methods 1994;173(1) 63-75.

[23] Montagnino G. Reappraisal of the clinical expression of mixed cryoglobulinemia. Springer Semin Immunopathol 1988;10(1) 1-19.

[24] Gorevic PD, Frangione B. Mixed cryoglobulinemia cross-reactive idiotypes: implications for the relationship of MC to rheumatic and lymphoproliferative diseases. Semin Hematol 1991;28(2) 79-94.

[25] Trendelenburg M, Schifferli JA. Cryoglobulins are not essential. Ann Rheum Dis 1998;57(1) 3-5.

[26] Pawlotsky JM, Ben Yahia M, Andre C, Voisin MC, Intrator L, Roudot-Thoraval F, et al. Immunological disorders in $\mathrm{C}$ virus chronic active hepatitis: a prospective casecontrol study. Hepatology 1994;19(4) 841-848.

[27] Dammacco F, Sansonno D. Mixed cryoglobulinemia as a model of systemic vasculitis. Clin Rev Allergy Immunol 1997;15(1) 97-119.

[28] Ramos-Casals M, Stone JH, Cid MC, Bosch X. The cryoglobulinaemias. Lancet 2012;379(9813) 348-360.

[29] Sansonno D, Cornacchiulo V, Iacobelli AR, Di Stefano R, Lospalluti M, Dammacco F. Localization of hepatitis $C$ virus antigens in liver and skin tissues of chronic hepatitis C virus-infected patients with mixed cryoglobulinemia. Hepatology 1995;21(2) 305-312.

[30] Matignon M, Cacoub P, Colombat M, Saadoun D, Brocheriou I, Mougenot B, et al. Clinical and morphologic spectrum of renal involvement in patients with mixed cryoglobulinemia without evidence of hepatitis C virus infection. Medicine (Baltimore) 2009;88(6) 341-348.

[31] Alpers CE, Smith KD. Cryoglobulinemia and renal disease. Curr Opin Nephrol Hypertens 2008;17(3) 243-249.

[32] Roccatello D, Fornasieri A, Giachino O, Rossi D, Beltrame A, Banfi G, et al. Multicenter study on hepatitis $C$ virus-related cryoglobulinemic glomerulonephritis. Am J Kidney Dis 2007;49(1) 69-82.

[33] Tarantino A, Campise M, Banfi G, Confalonieri R, Bucci A, Montoli A, et al. Longterm predictors of survival in essential mixed cryoglobulinemic glomerulonephritis. Kidney Int 1995;47(2) 618-623.

[34] Beddhu S, Bastacky S, Johnson JP. The clinical and morphologic spectrum of renal cryoglobulinemia. Medicine (Baltimore) 2002;81(5) 398-409. 
[35] D'Amico G. Renal involvement in hepatitis C infection: cryoglobulinemic glomerulonephritis. Kidney Int 1998;54(2) 650-671.

[36] Cordonnier DJ, Renversez JC, Vialtel P, Dechelette E. The kidney in mixed cryoglobulinemias. Springer Semin Immunopathol 1987;9(4) 395-415.

[37] Jennette JC, Olson JL, Schwartz MM, Silva FG, Heptinstall's Pathology of the Kidney. 6th ed. 2007, Philadelphia, Pa, USA.

[38] Sansonno D, Gesualdo L, Manno C, Schena FP, Dammacco F. Hepatitis C virus-related proteins in kidney tissue from hepatitis $C$ virus-infected patients with cryoglobulinemic membranoproliferative glomerulonephritis. Hepatology 1997;25(5) 1237-1244.

[39] Sansonno D, Lauletta G, Nisi L, Gatti P, Pesola F, Pansini N, et al. Non-enveloped $\mathrm{HCV}$ core protein as constitutive antigen of cold-precipitable immune complexes in type II mixed cryoglobulinaemia. Clin Exp Immunol 2003;133(2) 275-282.

[40] Authier FJ, Pawlotsky JM, Viard JP, Guillevin L, Degos JD, Gherardi RK. High incidence of hepatitis $C$ virus infection in patients with cryoglobulinemic neuropathy. Ann Neurol 1993;34(5) 749-750.

[41] Ferri C, Sebastiani M, Giuggioli D, Cazzato M, Longombardo G, Antonelli A, et al. Mixed cryoglobulinemia: demographic, clinical, and serologic features and survival in 231 patients. Semin Arthritis Rheum 2004;33(6) 355-374.

[42] Gemignani F, Melli G, Inglese C, Marbini A. Cryoglobulinemia is a frequent cause of peripheral neuropathy in undiagnosed referral patients. J Peripher Nerv Syst 2002;7(1) 59-64.

[43] Origgi L, Vanoli M, Carbone A, Grasso M, Scorza R. Central nervous system involvement in patients with HCV-related cryoglobulinemia. Am J Med Sci 1998;315(3) 208-210.

[44] Saadoun D, Asselah T, Resche-Rigon M, Charlotte F, Bedossa P, Valla D, et al. Cryoglobulinemia is associated with steatosis and fibrosis in chronic hepatitis C. Hepatology 2006;43(6) 1337-1345.

[45] Terrier B, Saadoun D, Sene D, Scerra S, Musset L, Cacoub P. Presentation and outcome of gastrointestinal involvement in hepatitis $C$ virus-related systemic vasculitis: a case-control study from a single-centre cohort of 163 patients. Gut 2010;59(12) 1709-1715.

[46] Ramos-Casals M, Robles A, Brito-Zeron P, Nardi N, Nicolas JM, Forns X, et al. Lifethreatening cryoglobulinemia: clinical and immunological characterization of 29 cases. Semin Arthritis Rheum 2006;36(3) 189-196.

[47] Retamozo S, Diaz-Lagares C, Bosch X, De Vita S, Ramos Casals M, Life-threatening cryoglobulinemia, in Autoimmune diseases: acute and complex situations., M.A. 
Khamashta and M. Ramos Casals, Editors. 2011, Springer-Verlag: London. p. 133-162.

[48] De Vita S, Soldano F, Isola M, Monti G, Gabrielli A, Tzioufas A, et al. Preliminary classification criteria for the cryoglobulinaemic vasculitis. Ann Rheum Dis 2011;70(7) 1183-1190.

[49] Levo Y, Gorevic PD, Kassab HJ, Zucker-Franklin D, Franklin EC. Association between hepatitis B virus and essential mixed cryoglobulinemia. N Engl J Med 1977;296(26) 1501-1504.

[50] Mascia MT, Ferrari D, Campioli D, Sandri G, Mussini C, Ferri C. Non HCV-related mixed cryoglobulinemia. Dig Liver Dis 2007;39 Suppl 1(S61-64.

[51] Pascual M, Perrin L, Giostra E, Schifferli JA. Hepatitis C virus in patients with cryoglobulinemia type II. J Infect Dis 1990;162(2) 569-570.

[52] Sansonno D, De Vita S, Cornacchiulo V, Carbone A, Boiocchi M, Dammacco F. Detection and distribution of hepatitis $C$ virus-related proteins in lymph nodes of patients with type II mixed cryoglobulinemia and neoplastic or non-neoplastic lymphoproliferation. Blood 1996;88(12) 4638-4645.

[53] Sansonno D, Lotesoriere C, Cornacchiulo V, Fanelli M, Gatti P, Iodice G, et al. Hepatitis $\mathrm{C}$ virus infection involves CD34(+) hematopoietic progenitor cells in hepatitis C virus chronic carriers. Blood 1998;92(9) 3328-3337.

[54] Rehermann B. Hepatitis C virus versus innate and adaptive immune responses: a tale of coevolution and coexistence. J Clin Invest 2009;119(7) 1745-1754.

[55] Dustin LB, Rice CM. Flying under the radar: the immunobiology of hepatitis C. Annu Rev Immunol 2007;25(71-99.

[56] Chen PP, Fong S, Goni F, Silverman GJ, Fox RI, Liu MF, et al. Cross-reacting idiotypes on cryoprecipitating rheumatoid factor. Springer Semin Immunopathol 1988;10(1) 35-55.

[57] Sansonno D, Iacobelli AR, Cornacchiulo V, Lauletta G, Distasi MA, Gatti P, et al. Immunochemical and biomolecular studies of circulating immune complexes isolated from patients with acute and chronic hepatitis C virus infection. Eur J Clin Invest 1996;26(6) 465-475.

[58] Curry MP, Golden-Mason L, Doherty DG, Deignan T, Norris S, Duffy M, et al. Expansion of innate CD5pos B cells expressing high levels of CD81 in hepatitis C virus infected liver. J Hepatol 2003;38(5) 642-650.

[59] Newkirk MM. Rheumatoid factors: host resistance or autoimmunity? Clin Immunol 2002;104(1) 1-13. 
[60] Charles ED, Green RM, Marukian S, Talal AH, Lake-Bakaar GV, Jacobson IM, et al. Clonal expansion of immunoglobulin $\mathrm{M}+\mathrm{CD} 27+\mathrm{B}$ cells in $\mathrm{HCV}$-associated mixed cryoglobulinemia. Blood 2008;111(3) 1344-1356.

[61] Lauletta G, Russi S, Conteduca V, Sansonno L. Hepatitis C virus infection and mixed cryoglobulinemia. Clin Dev Immunol 2012;2012(502156.

[62] Lindahl G, Sjobring U, Johnsson E. Human complement regulators: a major target for pathogenic microorganisms. Curr Opin Immunol 2000;12(1) 44-51.

[63] Kittlesen DJ, Chianese-Bullock KA, Yao ZQ, Braciale TJ, Hahn YS. Interaction between complement receptor $\mathrm{gC} 1 \mathrm{qR}$ and hepatitis $\mathrm{C}$ virus core protein inhibits T-lymphocyte proliferation. J Clin Invest 2000;106(10) 1239-1249.

[64] Yao ZQ, Ray S, Eisen-Vandervelde A, Waggoner S, Hahn YS. Hepatitis C virus: immunosuppression by complement regulatory pathway. Viral Immunol 2001;14(4) 277-295.

[65] Yao ZQ, Prayther D, Trabue C, Dong ZP, Moorman J. Differential regulation of SOCS-1 signalling in B and T lymphocytes by hepatitis $\mathrm{C}$ virus core protein. Immunology 2008;125(2) 197-207.

[66] Sansonno D, Tucci FA, Ghebrehiwet B, Lauletta G, Peerschke EI, Conteduca V, et al. Role of the receptor for the globular domain of $\mathrm{C} 1 \mathrm{q}$ protein in the pathogenesis of hepatitis C virus-related cryoglobulin vascular damage. J Immunol 2009;183(9) 6013-6020.

[67] Landau DA, Scerra S, Sene D, Resche-Rigon M, Saadoun D, Cacoub P. Causes and predictive factors of mortality in a cohort of patients with hepatitis $C$ virus-related cryoglobulinemic vasculitis treated with antiviral therapy. J Rheumatol 2010;37(3) 615-621.

[68] Della Rossa A, Tavoni A, D'Ascanio A, Catarsi E, Marchi F, Bencivelli W, et al. Mortality rate and outcome factors in mixed cryoglobulinaemia: the impact of hepatitis C virus. Scand J Rheumatol 2010;39(2) 167-170.

[69] Bonomo L, Casato M, Afeltra A, Caccavo D. Treatment of idiopathic mixed cryoglobulinemia with alpha interferon. Am J Med 1987;83(4) 726-730.

[70] Reddy KR, Wright TL, Pockros PJ, Shiffman M, Everson G, Reindollar R, et al. Efficacy and safety of pegylated (40-kd) interferon alpha-2a compared with interferon alpha-2a in noncirrhotic patients with chronic hepatitis C. Hepatology 2001;33(2) 433-438.

[71] Glue P, Fang JW, Rouzier-Panis R, Raffanel C, Sabo R, Gupta SK, et al. Pegylated interferon-alpha2b: pharmacokinetics, pharmacodynamics, safety, and preliminary efficacy data. Hepatitis C Intervention Therapy Group. Clin Pharmacol Ther 2000;68(5) 556-567. 
[72] Shepherd J, Brodin H, Cave C, Waugh N, Price A, Gabbay J. Pegylated interferon alpha-2a and $-2 b$ in combination with ribavirin in the treatment of chronic hepatitis $C$ : a systematic review and economic evaluation. Health Technol Assess 2004;8(39) iiiiv, 1-125.

[73] Cacoub P, Saadoun D, Limal N, Sene D, Lidove O, Piette JC. PEGylated interferon alfa- $2 b$ and ribavirin treatment in patients with hepatitis $C$ virus-related systemic vasculitis. Arthritis Rheum 2005;52(3) 911-915.

[74] Sansonno D, Lauletta G, De Re V, Tucci FA, Gatti P, Racanelli V, et al. Intrahepatic B cell clonal expansions and extrahepatic manifestations of chronic HCV infection. Eur J Immunol 2004;34(1) 126-136.

[75] Vallat L, Benhamou Y, Gutierrez M, Ghillani P, Hercher C, Thibault V, et al. Clonal B cell populations in the blood and liver of patients with chronic hepatitis $\mathrm{C}$ virus infection. Arthritis Rheum 2004;50(11) 3668-3678.

[76] Fan HB, Zhu YF, Chen AS, Zhou MX, Yan FM, Ma XJ, et al. B-cell clonality in the liver of hepatitis C virus-infected patients. World J Gastroenterol 2009;15(13) 1636-1640.

[77] Sansonno D, Lauletta G, Montrone M, Tucci FA, Nisi L, Dammacco F. Virological analysis and phenotypic characterization of peripheral blood lymphocytes of hepatitis C virus-infected patients with and without mixed cryoglobulinaemia. Clin Exp Immunol 2006;143(2) 288-296.

[78] Charles ED, Brunetti C, Marukian S, Ritola KD, Talal AH, Marks K, et al. Clonal B cells in patients with hepatitis $C$ virus-associated mixed cryoglobulinemia contain an expanded anergic CD21low B-cell subset. Blood 2011;117(20) 5425-5437.

[79] Cheung MC, Haynes AE, Meyer RM, Stevens A, Imrie KR, Members of the Hematology DSGotCCOPiE-BC. Rituximab in lymphoma: a systematic review and consensus practice guideline from Cancer Care Ontario. Cancer Treat Rev 2007;33(2) 161-176.

[80] Sanz I, Anolik JH, Looney RJ. B cell depletion therapy in autoimmune diseases. Front Biosci 2007;12(2546-2567.

[81] Barcellini W, Zanella A. Rituximab therapy for autoimmune haematological diseases. Eur J Intern Med 2011;22(3) 220-229.

[82] Sansonno D, De Re V, Lauletta G, Tucci FA, Boiocchi M, Dammacco F. Monoclonal antibody treatment of mixed cryoglobulinemia resistant to interferon alpha with an anti-CD20. Blood 2003;101(10) 3818-3826.

[83] Zaja F, De Vita S, Mazzaro C, Sacco S, Damiani D, De Marchi G, et al. Efficacy and safety of rituximab in type II mixed cryoglobulinemia. Blood 2003;101(10) 3827-3834.

[84] Visentini M, Ludovisi S, Petrarca A, Pulvirenti F, Zaramella M, Monti M, et al. A phase II, single-arm multicenter study of low-dose rituximab for refractory mixed 
cryoglobulinemia secondary to hepatitis C virus infection. Autoimmun Rev 2011;10(11) 714-719.

[85] Ferri C, Cacoub P, Mazzaro C, Roccatello D, Scaini P, Sebastiani M, et al. Treatment with rituximab in patients with mixed cryoglobulinemia syndrome: results of multicenter cohort study and review of the literature. Autoimmun Rev 2011;11(1) 48-55.

[86] Dammacco F, Tucci FA, Lauletta G, Gatti P, De Re V, Conteduca V, et al. Pegylated interferon-alpha, ribavirin, and rituximab combined therapy of hepatitis $C$ virus-related mixed cryoglobulinemia: a long-term study. Blood 2010;116(3) 343-353.

[87] Pietrogrande M, De Vita S, Zignego AL, Pioltelli P, Sansonno D, Sollima S, et al. Recommendations for the management of mixed cryoglobulinemia syndrome in hepatitis C virus-infected patients. Autoimmun Rev 2011;10(8) 444-454.

[88] Lok AS, Gardiner DF, Lawitz E, Martorell C, Everson GT, Ghalib R, et al. Preliminary study of two antiviral agents for hepatitis C genotype 1. N Engl J Med 2012;366(3) 216-224.

[89] Levine JW, Gota C, Fessler BJ, Calabrese LH, Cooper SM. Persistent cryoglobulinemic vasculitis following successful treatment of hepatitis $C$ virus. J Rheumatol 2005;32(6) 1164-1167.

[90] Landau DA, Saadoun D, Halfon P, Martinot-Peignoux M, Marcellin P, Fois E, et al. Relapse of hepatitis $C$ virus-associated mixed cryoglobulinemia vasculitis in patients with sustained viral response. Arthritis Rheum 2008;58(2) 604-611.

[91] Cheson BD. Ofatumumab, a novel anti-CD20 monoclonal antibody for the treatment of B-cell malignancies. J Clin Oncol 2010;28(21) 3525-3530.

[92] Ramunni A, Lauletta G, Brescia P, Saliani MT, Montrone M, Chironna M, et al. Double-filtration plasmapheresis in the treatment of leg ulcers in cryoglobulinemia. J Clin Apher 2008;23(3) 118-122.

[93] Talamo G, Zangari M, Novel therapeutic approaches to cryoglobulinemia: imatinib, infliximab, bortezomib, and beyond, in HCV infection and mixed cryoglobulinemia, F. Dammacco, Editor. 2012, Springer: Milan. p. 349-355.

[94] Saadoun D, Rosenzwajg M, Joly F, Six A, Carrat F, Thibault V, et al. Regulatory T-cell responses to low-dose interleukin-2 in HCV-induced vasculitis. $\mathrm{N}$ Engl J Med 2011;365(22) 2067-2077.

[95] Butel JS. Viral carcinogenesis: revelation of molecular mechanisms and etiology of human disease. Carcinogenesis 2000;21(3) 405-426.

[96] Raab-Traub N, Epstein-Barr virus, lymphoproliferative disease and nasopharingeal carcinoma., in Microbes and Malignancy. Infection and cause of human cancers., J. Parsonnet, Editor. 1999, Oxford University Press: Oxford. p. 180-206. 
[97] Martin D, Gutkind JS. Human tumor-associated viruses and new insights into the molecular mechanisms of cancer. Oncogene 2008;27 Suppl 2(S31-42.

[98] Boxus M, Willems L. Mechanisms of HTLV-1 persistence and transformation. Br J Cancer 2009;101(9) 1497-1501.

[99] Ganem D. KSHV and the pathogenesis of Kaposi sarcoma: listening to human biology and medicine. J Clin Invest 2010;120(4) 939-949.

[100] Dammacco F, Gatti P, Sansonno D. Hepatitis C virus infection, mixed cryoglobulinemia, and non-Hodgkin's lymphoma: an emerging picture. Leuk Lymphoma 1998;31(5-6) 463-476.

[101] Ferri C, Caracciolo F, Zignego AL, La Civita L, Monti M, Longombardo G, et al. Hepatitis $\mathrm{C}$ virus infection in patients with non-Hodgkin's lymphoma. Br J Haematol 1994;88(2) 392-394.

[102] Pozzato G, Mazzaro C, Crovatto M, Modolo ML, Ceselli S, Mazzi G, et al. Low-grade malignant lymphoma, hepatitis $\mathrm{C}$ virus infection, and mixed cryoglobulinemia. Blood 1994;84(9) 3047-3053.

[103] Dal Maso L, Franceschi S. Hepatitis C virus and risk of lymphoma and other lymphoid neoplasms: a meta-analysis of epidemiologic studies. Cancer Epidemiol Biomarkers Prev 2006;15(11) 2078-2085.

[104] Mussini C, Ghini M, Mascia MT, Giovanardi P, Zanni G, Lattuada I, et al. Monoclonal gammopathies and hepatitis C virus infection. Blood 1995;85(4) 1144-1145.

[105] Martyak LA, Yeganeh M, Saab S. Hepatitis C and lymphoproliferative disorders: from mixed cryoglobulinemia to non-Hodgkin's lymphoma. Clin Gastroenterol Hepatol 2009;7(8) 900-905.

[106] Matsuo K, Kusano A, Sugumar A, Nakamura S, Tajima K, Mueller NE. Effect of hepatitis $\mathrm{C}$ virus infection on the risk of non-Hodgkin's lymphoma: a meta-analysis of epidemiological studies. Cancer Sci 2004;95(9) 745-752.

[107] De Vita S, Sacco C, Sansonno D, Gloghini A, Dammacco F, Crovatto M, et al. Characterization of overt B-cell lymphomas in patients with hepatitis $\mathrm{C}$ virus infection. Blood 1997;90(2) 776-782.

[108] Ryan J, Wallace S, Jones P, Taggart G, Dudley F. Primary hepatic lymphoma in a patient with chronic hepatitis C. J Gastroenterol Hepatol 1994;9(3) 308-310.

[109] Vallisa D, Berte R, Rocca A, Civardi G, Giangregorio F, Ferrari B, et al. Association between hepatitis $C$ virus and non-Hodgkin's lymphoma, and effects of viral infection on histologic subtype and clinical course. Am J Med 1999;106(5) 556-560.

[110] Giordano TP, Henderson L, Landgren O, Chiao EY, Kramer JR, El-Serag H, et al. Risk of non-Hodgkin lymphoma and lymphoproliferative precursor diseases in US veterans with hepatitis C virus. JAMA 2007;297(18) 2010-2017. 
[111] Sene D, Ghillani-Dalbin P, Thibault V, Guis L, Musset L, Duhaut P, et al. Longterm course of mixed cryoglobulinemia in patients infected with hepatitis $C$ virus. J Rheumatol 2004;31(11) 2199-2206.

[112] Viswanatha DS, Dogan A. Hepatitis C virus and lymphoma. J Clin Pathol 2007;60(12) 1378-1383.

[113] de Sanjose S, Benavente Y, Vajdic CM, Engels EA, Morton LM, Bracci PM, et al. Hepatitis $\mathrm{C}$ and non-Hodgkin lymphoma among 4784 cases and 6269 controls from the International Lymphoma Epidemiology Consortium. Clin Gastroenterol Hepatol 2008;6(4) 451-458.

[114] Saadoun D, Suarez F, Lefrere F, Valensi F, Mariette X, Aouba A, et al. Splenic lymphoma with villous lymphocytes, associated with type II cryoglobulinemia and HCV infection: a new entity? Blood 2005;105(1) 74-76.

[115] Arcaini L, Burcheri S, Rossi A, Paulli M, Bruno R, Passamonti F, et al. Prevalence of $\mathrm{HCV}$ infection in nongastric marginal zone B-cell lymphoma of MALT. Ann Oncol 2007;18(2) 346-350.

[116] Saadoun D, Bieche I, Maisonobe T, Asselah T, Laurendeau I, Piette JC, et al. Involvement of chemokines and type 1 cytokines in the pathogenesis of hepatitis $C$ virus-associated mixed cryoglobulinemia vasculitis neuropathy. Arthritis Rheum 2005;52(9) 2917-2925.

[117] Scarselli E, Ansuini H, Cerino R, Roccasecca RM, Acali S, Filocamo G, et al. The human scavenger receptor class $\mathrm{B}$ type $\mathrm{I}$ is a novel candidate receptor for the hepatitis $\mathrm{C}$ virus. EMBO J 2002;21(19) 5017-5025.

[118] Agnello V, Abel G, Elfahal M, Knight GB, Zhang QX. Hepatitis C virus and other flaviviridae viruses enter cells via low density lipoprotein receptor. Proc Natl Acad Sci U S A 1999;96(22) 12766-12771.

[119] Petracca R, Falugi F, Galli G, Norais N, Rosa D, Campagnoli S, et al. Structure-function analysis of hepatitis C virus envelope-CD81 binding. J Virol 2000;74(10) 4824-4830.

[120] Zuckerman E, Kessel A, Slobodin G, Sabo E, Yeshurun D, Toubi E. Antiviral treatment down-regulates peripheral B-cell CD81 expression and CD5 expansion in chronic hepatitis C virus infection. J Virol 2003;77(19) 10432-10436.

[121] Laporte J, Bain C, Maurel P, Inchauspe G, Agut H, Cahour A. Differential distribution and internal translation efficiency of hepatitis $C$ virus quasispecies present in dendritic and liver cells. Blood 2003;101(1) 52-57.

[122] Kronenberger B, Sarrazin C, Hofmann WP, von Wagner M, Herrmann E, Welsch C, et al. Mutations in the putative HCV-E2 CD81 binding regions and correlation with cell surface CD81 expression. J Viral Hepat 2004;11(4) 310-318. 
[123] Pal S, Sullivan DG, Kim S, Lai KK, Kae J, Cotler SJ, et al. Productive replication of hepatitis $C$ virus in perihepatic lymph nodes in vivo: implications of HCV lymphotropism. Gastroenterology 2006;130(4) 1107-1116.

[124] Sansonno D, Tucci FA, Lauletta G, De Re V, Montrone M, Troiani L, et al. Hepatitis C virus productive infection in mononuclear cells from patients with cryoglobulinaemia. Clin Exp Immunol 2007;147(2) 241-248.

[125] Dahari H, Feliu A, Garcia-Retortillo M, Forns X, Neumann AU. Second hepatitis C replication compartment indicated by viral dynamics during liver transplantation. J Hepatol 2005;42(4) 491-498.

[126] Sansonno D, De Vita S, Iacobelli AR, Cornacchiulo V, Boiocchi M, Dammacco F. Clonal analysis of intrahepatic B cells from HCV-infected patients with and without mixed cryoglobulinemia. J Immunol 1998;160(7) 3594-3601.

[127] Aarts WM, Bende RJ, Steenbergen EJ, Kluin PM, Ooms EC, Pals ST, et al. Variable heavy chain gene analysis of follicular lymphomas: correlation between heavy chain isotype expression and somatic mutation load. Blood 2000;95(9) 2922-2929.

[128] De Re V, De Vita S, Marzotto A, Rupolo M, Gloghini A, Pivetta B, et al. Sequence analysis of the immunoglobulin antigen receptor of hepatitis $C$ virus-associated nonHodgkin lymphomas suggests that the malignant cells are derived from the rheumatoid factor-producing cells that occur mainly in type II cryoglobulinemia. Blood 2000;96(10) 3578-3584.

[129] Ishak KG. Chronic hepatitis: morphology and nomenclature. Mod Pathol 1994;7(6) 690-713.

[130] Mosnier JF, Degott C, Marcellin P, Henin D, Erlinger S, Benhamou JP. The intraportal lymphoid nodule and its environment in chronic active hepatitis $\mathrm{C}$ : an immunohistochemical study. Hepatology 1993;17(3) 366-371.

[131] Racanelli V, Sansonno D, Piccoli C, D'Amore FP, Tucci FA, Dammacco F. Molecular characterization of $\mathrm{B}$ cell clonal expansions in the liver of chronically hepatitis $\mathrm{C}$ virus-infected patients. J Immunol 2001;167(1) 21-29.

[132] Cheema GS, Roschke V, Hilbert DM, Stohl W. Elevated serum B lymphocyte stimulator levels in patients with systemic immune-based rheumatic diseases. Arthritis Rheum 2001;44(6) 1313-1319.

[133] Zignego AL, Ferri C, Giannelli F, Giannini C, Caini P, Monti M, et al. Prevalence of bcl-2 rearrangement in patients with hepatitis $C$ virus-related mixed cryoglobulinemia with or without B-cell lymphomas. Ann Intern Med 2002;137(7) 571-580.

[134] Sansonno D, Tucci FA, De Re V, Lauletta G, Montrone M, Libra M, et al. HCV-associated $\mathrm{B}$ cell clonalities in the liver do not carry the $\mathrm{t}(14 ; 18)$ chromosomal translocation. Hepatology 2005;42(5) 1019-1027. 
[135] Durandy A. Activation-induced cytidine deaminase: a dual role in class-switch recombination and somatic hypermutation. Eur J Immunol 2003;33(8) 2069-2073.

[136] Kuppers R, Dalla-Favera R. Mechanisms of chromosomal translocations in B cell lymphomas. Oncogene 2001;20(40) 5580-5594.

[137] Pasqualucci L, Neumeister P, Goossens T, Nanjangud G, Chaganti RS, Kuppers R, et al. Hypermutation of multiple proto-oncogenes in B-cell diffuse large-cell lymphomas. Nature 2001;412(6844) 341-346.

[138] Chiba T, Marusawa H. A novel mechanism for inflammation-associated carcinogenesis; an important role of activation-induced cytidine deaminase (AID) in mutation induction. J Mol Med (Berl) 2009;87(10) 1023-1027.

[139] Kawamura Y, Ikeda K, Arase Y, Yatsuji H, Sezaki H, Hosaka T, et al. Viral elimination reduces incidence of malignant lymphoma in patients with hepatitis C. Am J Med 2007;120(12) 1034-1041.

[140] Hermine O, Lefrere F, Bronowicki JP, Mariette X, Jondeau K, Eclache-Saudreau V, et al. Regression of splenic lymphoma with villous lymphocytes after treatment of hepatitis C virus infection. N Engl J Med 2002;347(2) 89-94.

[141] Gisbert JP, Garcia-Buey L, Pajares JM, Moreno-Otero R. Systematic review: regression of lymphoproliferative disorders after treatment for hepatitis $\mathrm{C}$ infection. Aliment Pharmacol Ther 2005;21(6) 653-662.

[142] Arcaini L, Merli M, Volpetti S, Rattotti S, Gotti M, Zaja F. Indolent B-cell lymphomas associated with HCV infection: clinical and virological features and role of antiviral therapy. Clin Dev Immunol 2012;2012(638185.

[143] Isaacson PG, Piris MA, Berger F, Swerdlow SH, Thieblemont C, Pittaluga S, et al., Splenic B-cell marginal zone lymphoma, in WHO classification of tumours of haematopoietic and lymphoid tissues., S.H. Swerdlow, et al., Editors. 2008, IARC Press: Lyon. p. 85-187.

[144] Saadoun D, Resche Rigon M, Sene D, Terrier B, Karras A, Perard L, et al. Rituximab plus Peg-interferon-alpha/ribavirin compared with Peg-interferon-alpha/ribavirin in hepatitis C-related mixed cryoglobulinemia. Blood 2010;116(3) 326-334; quiz 504-325.

[145] Pellicelli AM, Marignani M, Zoli V, Romano M, Morrone A, Nosotti L, et al. Hepatitis C virus-related B cell subtypes in non Hodgkin's lymphoma. World J Hepatol 2011;3(11) 278-284.

[146] Iannitto E, Ammatuna E, Tripodo C, Marino C, Calvaruso G, Florena AM, et al. Long-lasting remission of primary hepatic lymphoma and hepatitis $C$ virus infection achieved by the alpha-interferon treatment. Hematol J 2004;5(6) 530-533. 
[147] Levine AM, Shimodaira S, Lai MM. Treatment of HCV-related mantle-cell lymphoma with ribavirin and pegylated interferon Alfa. N Engl J Med 2003;349(21) 2078-2079.

[148] Ennishi D, Maeda Y, Niitsu N, Kojima M, Izutsu K, Takizawa J, et al. Hepatic toxicity and prognosis in hepatitis $\mathrm{C}$ virus-infected patients with diffuse large B-cell lymphoma treated with rituximab-containing chemotherapy regimens: a Japanese multicenter analysis. Blood 2010;116(24) 5119-5125.

[149] Musto P, Dell'Olio M, La Sala A, Mantuano S, Cascavilla N. Diffuse B-Large Cell Lymphomas (DBLCL) with Hepatitis-C Virus (HCV) Infection: Clinical Outcome and Preliminary Results of a Pilot Study Combining R-CHOP with Antiviral Therapy. Blood 2005;106(11) 2447.

[150] La Mura V, De Renzo A, Perna F, D'Agostino D, Masarone M, Romano M, et al. Antiviral therapy after complete response to chemotherapy could be efficacious in HCVpositive non-Hodgkin's lymphoma. J Hepatol 2008;49(4) 557-563. 
